\title{
PENGARUH KUALITAS KERJA TERHADAP KINERJA BANK BNI SYARIAH CABANG BOGOR
}

\author{
Barlian Wijaksono $^{*}$, Aida Vitayala Hubeis ${ }^{* *)}$, dan Imam Teguh Saptono*) \\ *) Sekolah Bisnis, Institut Pertanian Bogor \\ Jl. Raya Pajajaran, Bogor 16151 \\ **) Departemen Departemen Sains Komunikasi dan Pengembangan Masyarakat, \\ Fakultas Ekologi Manusia, Institut Pertanian Bogor \\ Jl. Kamper, Wing 1, Level 5, Kampus IPB Darmaga Bogor 16680
}

\begin{abstract}
The purposes this research were analyzing the relationship between the characteristics of the employees and performance, analyzing the quality of the employee performance at Bank BNI Syariah Bogor, analyzing differences in the quality of the employee performance between male and female employees at Bank BNI Syariah Bogor, and as well as formulating the variables that can increase the quality of the performance of the employees of Bank BNI Syariah Bogor Branch. Based on the results in which the analysis used multiple linear regression, a conclusion can be taken from the study. The characteristics of the employees of BNI Syariah Bank which dominantly influences the performance include age range between 26-30 years, a university degree (S1), working year of 2-5 years, and frontliner position. Overall, the variables that affect the quality of the male and female employee performance of Bank BNI Syariah Bogor Branch include knowledge, working skill, behavior, and working experience. Based on the results, in terms of the quality the male employees, the variables that increase the performance quality at Bank BNI Syariah Bogor are only behavior and work experience, while for the female employees, there is no variable influencing the improvement of their performance quality in bank BNI Syariah Bogor. After conducting the testing on quality, the result shows that only male employees will increase their quality performance but only with variables of behavior and working experience.
\end{abstract}

Keywords: gender, BNI Syariah, multiple linear regressions, quality of the employee, performance

\begin{abstract}
ABSTRAK
Tujuan dari penelitian ini yaitu menganalisis hubungan karakteristik karyawan dengan kinerja, menganalisis kualitas kinerja karyawan, menganalisis perbedaan kualitas kinerja karyawan antara gender laki-laki dengan perempuan, serta merumuskan variabelvariabel yang dapat meningkatkan kualitas kinerja karyawan Bank BNI Syariah Cabang Bogor. Penelitian ini menggunakan analisis Multiple Linear Regression. Hasil penelitian menunjukkan bahwa karakteristik karyawan Bank BNI Syariah Bogor yang dominan memengaruhi kinerja umumnya berusia antara 26-30 tahun, memiliki tingkat pendidikan sarjana (S1), lama bekerja 2-5 tahun, dan memiliki jabatan sebagai frontliner. Secara keseluruhan variabel-variabel yang memengaruhi kualitas kinerja karyawan laki-laki dan perempuan di Bank BNI Syariah Cabang Bogor adalah knowledge, working skill, behaviour, dan working experience. Hasil analisis secara kuantitas untuk karyawan lakilaki, variabel-variabel yang berpengaruh dalam meningkatkan kualitas kinerja di Bank BNI Syariah Cabang Bogor hanya variabel perilaku dan pengalaman kerja, sedangkan untuk karyawan perempuan tidak ada satu variabel pun yang berpengaruh dalam meningkatkan kualitas kinerja di Bank BNI Syariah Cabang Bogor. Setelah dilakukan pengujian kualitas hasil hanya gender laki-laki yang dapat meningkatkan kualitas kinerja karyawan Bank BNI Syariah, tetapi dengan catatan hanya variabel perilaku dan pengalaman kerja saja.
\end{abstract}

Kata kunci: gender, BNI Syariah, multiple linear regression, kualitas kerja, kinerja

\footnotetext{
${ }^{1}$ Alamat Korespondensi:

Email: barlian48@gmail.com
} 


\section{PENDAHULUAN}

Bank BNI Syariah salah satu bank syariah yang berkembang sangat cepat, terlihat dari semakin banyaknya cabang-cabang baru di kota-kota besar. Secara umum Bank BNI Syariah di Indonesia kinerja karyawannya meningkat dari tahun ke tahun berdasarkan laporan tahunan, akan tetapi khusus di Bank BNI Syariah Cabang Bogor terjadi penurunan kualitas kinerja karyawan pada tahun 2014. Penurunan kualitas kerja tersebut akan diikuti oleh penurunan kinerja.

Menurut Prawirasentono (1999) penurunan kinerja karyawan disebabkanoleh berbagai faktor. Faktor-faktor tersebut diantaranya adalah usia, pendidikan, status perkawinan, jabatan, gaji, dan jenis kelamin. Penilaian kualitas kinerja karyawan Bank BNI Syariah Cabang Bogor perlu dilakukan karena merupakan perusahaan besar yang berkembang sangat cepat. Penilaian kinerja dideskripsikan sebagai suatu pencapaian tugas yang diberikan sesuai dengan pedoman organisasi atau perusahaan yang tunduk pada norma-norma yang ada untuk mengatasi permasalahan dengan memanfaatkan sumber daya yang tersedia (Jamal, 1984). Hasil analisis yang dilakukan Rivai et al. (2006) dan Syafi'i (2015) sejumlah besar responden bank konvensional saat ini masih tertarik dan mempertimbangkan untuk pindah ke bank syariah.

Bank BNI Syariah Cabang Bogor memiliki jumlah karyawan berjenis kelamin perempuan lebih banyak dibandingkan dengan jenis kelamin laki-laki. Faktor jenis kelamin diambil terkait isu yang berkembang saat ini, dimana perempuan dituntut berkarir dan bekerja untuk kesejahteraan keluarganya. Selain itu perempuan modern berperan sangat penting dalam semua sektor pembangunan. Oleh sebab itu, faktor jenis kelamin pada Bank BNI Syariah Cabang Bogor perlu dilakukan analisis kualitas kinerja. Secara terminologis, gender didefinisikan sebagai harapan-harapan budaya terhadap laki-laki dan perempuan (Lips HM 1993, Showalter 1989). Menurut Channar et al. (2011) bahwa karyawan perempuan yang bekerja di perusahaan swasta mengalami diskriminasi gender lebih tinggi dibandingkan karyawan laki-laki dan berdampak pada menurunnya kepuasan, motivasi, komitmen, tingkat antusias karyawan, dan menaikkan tingkat stress karyawan.
Herzberg (1974) mengembangkan teori motivasi ada dua faktor. Menurut teori ini ada dua faktor yang memengaruhi kondisi pekerjaan seseorang, yaitu faktor pemuas (motivation factors) yang disebut juga dengan satisfier atau intrinsic motivation dan faktor kesehatan (hygiene) yang juga disebut disatisfier atau ekstrinsic motivation. Menurut Edrak et al. (2013) bahwa tidak ada perbedaan motivasi intrinsik dan ekstrinsik pada karyawan laki-laki dan perempuan. Menurut Gibson (1996) secara teroritis ada tiga kelompok variabel yang memengaruhi kinerja yaitu variabel individu (pengetahuan, keterampilan kerja, dan pengalaman kerja), variabel demografis (perilaku) dan variabel psikologis (motivasi). Motivasi berpengaruh secara signifikan terhadap kinerja karyawan (Zameer et al. 2014).

Menurut Mangkunegara (2000) faktor-faktor yang memengaruhi pencapaian kinerja adalah pengetahuan (knowledge), keterampilan (skill), dan faktor motivasi (motivation). Pada penelitian ini variabelvariabel yang diambil untuk dilakukan analisis, yaitu pengetahuan, keterampilan kerja, perilaku (Siddiqah, 2010; Ekowarni 2001; dan Cornell et al. 1999) dan pengalaman kerja (Setiawan, 2015). Menurut penelitian Putri (2000) tingkat pengetahuan sikap mempunyai pengaruh terhadap perilaku. Menurut Zainullah (2012) dan Sulaeman (2014) pengalaman kerja mempunyai pengaruh yang signifikan terhadap kinerja pekerjaan.

Berdasarkan perumusan masalah maka penelitian ini bertujuan menganalisis hubungan karakteristik karyawan dengan kinerja, menganalisis kualitas kinerja karyawan, menganalisis perbedaan kualitas kinerja karyawan antara laki-laki dengan perempuan di Bank BNI Syariah Cabang Bogor, dan merumuskan variabelvariabel yang dapat meningkatkan kualitas kinerja (Riorini, 2004) karyawan Bank BNI Syariah Cabang Bogor.

\section{METODE PENELITIAN}

Penelitian ini dilaksanakan di Bank BNI Syariah Cabang Bogor pada bulan Januari 2016 sampai dengan bulan Juli 2016. Pemilihan lokasi penelitian ini didasarkan adanya penurunan kinerja karyawan ditahun 2014 di Bank BNI Syariah Bogor. 
Jenis data yang digunakan dalam penelitian ini adalah data kualitatif yang bersifat nominal dan ordinal, dimana digunakan untuk mengetahui kualitas kinerja responden karyawan Bank BNI Syariah Cabang Bogor. Sumber data penelitian ini adalah data primer yang diperoleh melalui survei dengan menggunakan instrumen kuesioner sebagai alat pengumpulan data. Objek pada penelitian ini adalah seluruh karyawan tetap yang bekerja Bank BNI Syariah Cabang Bogor berjumlah 51 orang. Data diperoleh dengan cara menyebarkan kuesioner kepada responden, yaitu pimpinan cabang, manajer operasional, manajer bisnis, pimpinan penyelia, analis pembiayaan, marketing, collection, customer service, dan teller. Pengumpulan data sekunder diperlukan untuk mengetahui kualitas masing-masing kinerja karyawan bank BNI Syariah Cabang Bogor antara kinerja laki-laki dan kinerja perempuan. dan melakukan observasi dengan menggunakan daftar absensi checklist untuk mengetahui kinerja karyawan Bank BNI Syariah Cabang Bogor. Kuesioner disusun dengan menggunakan skala likert 1-5, dimana angka 1 menunjukkan sangat tidak setuju, angka 2 tidak setuju, angka 3 cukup setuju, angka 4 setuju, dan angka 5 sangat setuju.

Penelitian ini dimaksudkan untuk menjelaskan kedudukan-kedudukan variabel yang akan diteliti serta hubungan antar satu variabel dengan variabel yang lain atau dengan kata lain untuk melihat hubungan variabel independen (pengetahuan, keterampilan kerja, perilaku, dan pengalaman kerja) terhadap variabel dependen (kinerja karyawan). Menurut John L et al. (2008) beberapa sifat, jalan pemikiran, dan perilaku diikat secara biologis dan tidak diperoleh dari pembelanjaran atau faktor situasional, tetapi dari pengaruh pembawaan sejak lahir. Penelitian ini diarahkan untuk menggambarkan adanya pengaruh masing-masing variabel terhadap kualitas kinerja karyawan dan atas dasar itulah kemudian akan ditarik kesimpulan umum. Untuk mendapatkan kesimpulan masing-masing variabel dalam penelitian ini, maka metode analisis data yang digunakan adalah analisis regresi linear berganda. Hipotesis-hipotesis alternatif yang diajukan dalam penelitian ini adalah sebagai berikut:

H0 : Ada pengaruh yang positif dan signifikan antara pengetahuan kerja terhadap kinerja karyawan
H1 : Tidak ada pengaruh yang positif dansignifikan antara pengetahuan kerja terhadap kinerja karyawan

H0 : Ada pengaruh yang positif dan signifikan antara keterampilan kerja terhadap kinerjakaryawan

H1 : Tidak ada pengaruh yang positif dansignifikan antara keterampilan kerja terhadap kinerja karyawan

H0 : Ada pengaruh yang positif dan signifikanantara perilaku terhadap kinerja karyawan

H1 : Tidak ada pengaruh yang positif dan ignifikan antara perilaku terhadap kinerja karyawan

H0 : Ada pengaruh yang positif dan signifikanantara pengalaman kerja terhadap kinerja karyawan

H1 : Tidak ada pengaruh yang positif dansignifikan antara pengalaman kerja terhadap kinerja karyawan

Setelah diperoleh hasil hipotesis-hipotesis yang diajukan dari masing-masing jenis kelamin maka akan diperoleh hasil perbandingan kualitas kinerja antara karyawan laki-laki dan perempuan.

Kerangka pemikiran penelitan ini membahas mengenai analisis penilaian kinerja karyawan Bank BNI Syariah Cabang Bogor berdasarkan kualitas. Waterhouse dan Svendsen (1998) mendefinisikan kinerja merupakan releksi dari pencapaian kuantitas dan kualitas pekerjaan yang dihasilkan individu, kelompok atau organisasi, dan dapat diukur. Penelitian ini diawali dengan melihat adanya penurunan kinerja karyawan Bank BNI Syariah Cabang Bogor tahun 2014. Maka berikutnya akan diberikan rekomendasi untuk pengembangan strategi bagi perusahaan terkait. Selanjutnya, kerangka pemikiran dalam penelitian ini adalah untuk mengetahui pengaruh masing-masing variabel pengetahuan kerja, keterampilan, perilaku, dan pengalaman kerja terhadap kinerja karyawan pada Bank BNI Syariah Bogor. Setelah mengetahui pengaruh masing-masing variabel independen terhadap variabel dependen, maka berikutnya akan diberikan rekomendasi untuk pengembangan strategi bagi perusahaan terkait. Kerangka pemikiran penelitian selengkapnya pada Gambar 1. 


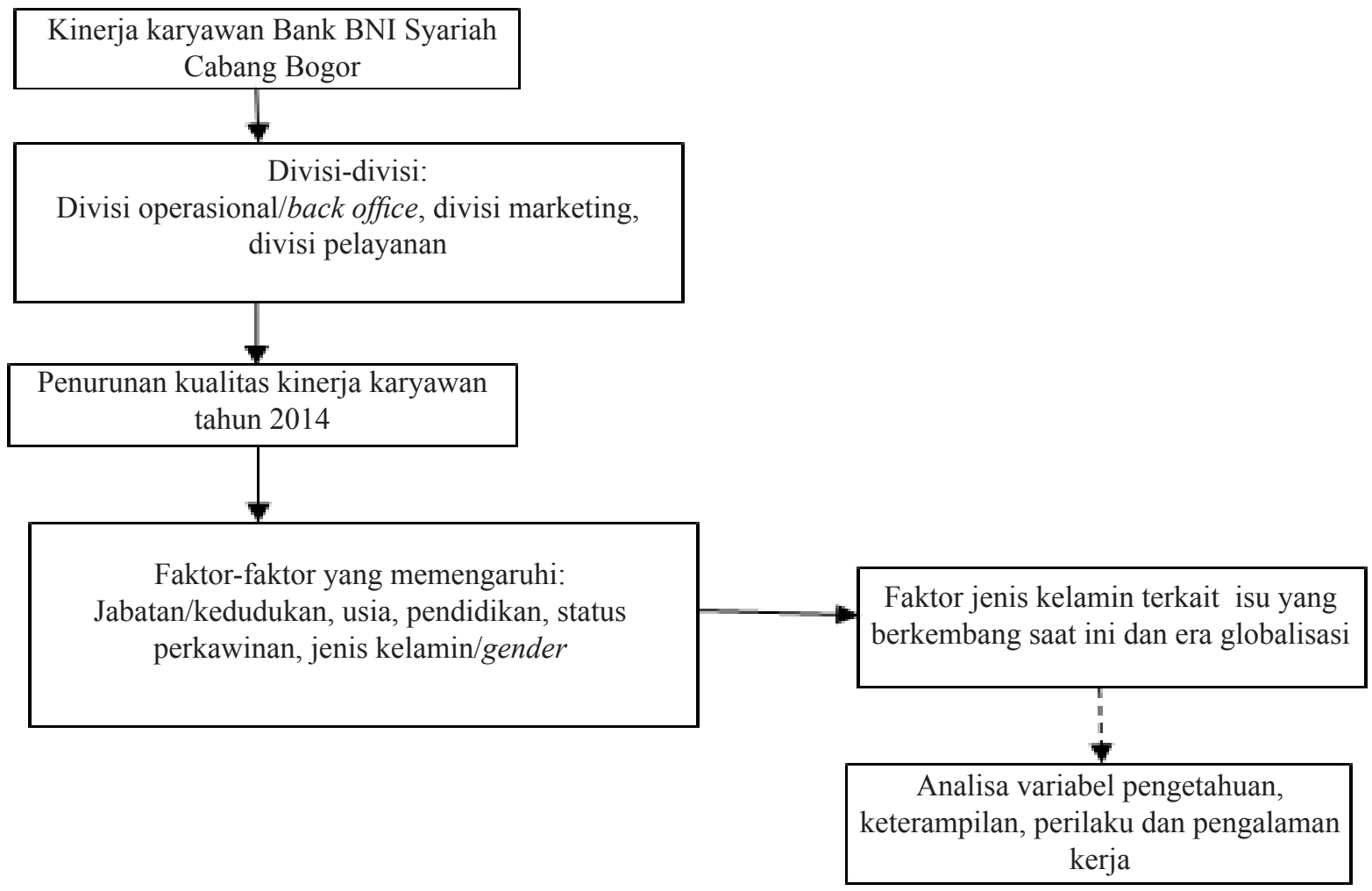

Gambar 1. Kerangka pemikiran penelitian

\section{HASIL}

\section{Hubungan Karakteristik Karyawan dengan Kinerja}

Jumlah karyawan Bank BNI Syariah Cabang Bogor sebanyak 51 orang yang terdiri dari laki-laki sebanyak 23 orang dan 28 orang perempuan. Karyawan Bank BNI Syariah Bogor memiliki karakteristik yang ditunjukkan pada Tabel 1.

Karakteristik karyawan Bank BNI Syariah didominasi oleh karyawan perempuan berjumlah 28 orang pada Tabel 1. Karyawan Bank BNI Syariah Bogor didominasi oleh karyawan yang berusia 26-30 tahun sebesar $45,1 \%$, tingkat pendidikan sarjana ( 1 1) sebesar $64,7 \%$, masa kerja 2-5 tahun sebesar $43,1 \%$, dan memiliki posisi atau jabatan sebagai fronliner sebesar $37,3 \%$. Ada yang menarik pada Tabel 1 dimana jumlah pimpinan perempuan lebih banyak dibandingkan lakilaki, hal tersebut sesuai dengan penelitian Dimovski et al. (2010) menyatakan bahwa eksploratori dilakukan dengan melibatkan perempuan yang memiliki posisi sebagai manajer dalam sebuah perusahaan. Hasil menunjukkan karyawan jenis kelamin perempuan memiliki tingkat pendidikan pascasarjana lebih banyak (3 orang) daripada laki-laki (2 orang). Hasil penelitian tersebut sesuai dengan pendapat Eisner dan Harvey (2009) yang menyatakan bahwa meskipun saat ini laki-laki dan perempuan yang bekerja memiliki tingkat pendidikan yang sama. Namun, perempuan lebih banyak yang memperoleh gelar dibandingkan lakilaki. Karyawan perempuan yang berumur lebih dari 35 tahun hanya berjumlah tiga orang, hasil tersebut sesuai dengan penelitian Wijayanti (2009) menyatakan bahwa salah satu faktor yang menghambat perkembangan karir perempuan adalah umur, dimana perempuan yang ingin mencapai posisi yang lebih tinggi seringkali terhalang dengan umur yang dianggap sudah tidak produktif.

\section{Kualitas Kinerja Karyawan Bank BNI Syariah}

Langkah awal dalam analisis data yaitu variabelvariabel yang ditentukan, variabel-variabel yang ditentukan berdasarkan literatur yang diperoleh pada penelitian ini yaitu pengetahuan, keterampilan kerja, perilaku, dan pengalaman kerja. Variabel-variabel yang telah dipilih kemudian dilakukan uji kualitas data diantaranya uji reliabilitas dan uji validitas. 
Sebelum dilakukan pengujian R-squared, data diukur reliabilitas dan validitasya agar data yang diperoleh benar-benar handal dan dapat mengukur apa yang diinginkan. Tes reliabilitas dilakukan untuk mengetahui sejauhmana hasil pengukuran dua kali atau lebih terhadap objek yang sama dengan alat pengukur yang sama, teknik yang digunakan adalah Cronbach Alpha (Ghozali, 2003).

Uji kualitas data yang dilakukan pada penelitian ini diperoleh pada Tabel 2 nilai uji reliabilitas untuk masing-masing variabel lebih besar 0,60 sehingga dapat diperoleh kesimpulan variabel-variabel yang diukur pada uji reliabilitas bersifat reliabel. Artinya, variabelvariabel yang diukur pada penelitian ini baik karyawan laki-laki dan karyawan perempuan Bank BNI Syariah Bogor dapat dilakukan uji selanjutnya.

Hasil uji validitas untuk masing-masing variabel pada Tabel 3 diperoleh P-Val < alpha (5\%). Artinya, untuk uji validitas pada penelitian ini bersifat tolak $\mathrm{HO}$ atau tidak ada korelasi antara butir pertanyaan dengan variabel yang diukur, dimaksud tolak $\mathrm{H} 0$ artinya pada butir-butir pertanyaan masing-masing variabel ada hubungannya dengan variabel-variabel yang diukur. Variabel-variabel pengetahuan, keterampilan kerja, perilaku, dan pengalaman kerja dalam penelitian ini bisa dijadikan indikator-indikator penilaian kinerja karyawan Bank BNI Syariah Cabang Bogor untuk karyawan laki-laki dan perempuan.

Uji asumsi klasik dilakukan untuk mengetahui kondisi data yang ada agar dapat menentukan model analisis yang paling tepat digunakan. Uji asumsi klasik dalam penelitian ini terdiri dari secara eksploratif dengan hanya melihat sebaran titik pada diagram dan Uji Formal menggunakan Uji Kehomogenan Ragam menggunakan Uji Gletsjer, Uji normalitas dengan menggunakan Uji Kolmogorov Smirnov, Uji Kebebasan Sisaan menggunakan Uji Durbin Watson, dan Uji Multikolinieritas dengan melihat VIF (Varience Inflation Factors).

Tabel 1. Karakteristik karyawan Bank BNI Syariah Bogor

\begin{tabular}{|c|c|c|c|c|c|}
\hline \multicolumn{2}{|c|}{ Karakteristik } & Laki-Laki & Perempuan & Total & Persentase $(\%)$ \\
\hline \multirow[t]{4}{*}{ Usia (tahun) } & $<25$ & 1 & 12 & 13 & 25,5 \\
\hline & $26-30$ & 13 & 10 & 23 & 45,1 \\
\hline & $31-35$ & 4 & 3 & 7 & 13,7 \\
\hline & $>35$ & 5 & 3 & 8 & 15,7 \\
\hline \multirow[t]{3}{*}{ Pendidikan } & D3 & 5 & 8 & 13 & 25,5 \\
\hline & S1 & 16 & 17 & 33 & 64,7 \\
\hline & S2 & 2 & 3 & 5 & 9,8 \\
\hline \multirow{4}{*}{$\begin{array}{l}\text { Lama Bekerja } \\
\text { (tahun) }\end{array}$} & $<2$ & 1 & 3 & 4 & 7,8 \\
\hline & $2-5$ & 9 & 13 & 22 & 43,1 \\
\hline & $5-10$ & 11 & 9 & 20 & 39,2 \\
\hline & $>10$ & 2 & 3 & 5 & 9,8 \\
\hline \multirow[t]{4}{*}{ Jabatan } & Pimpinan & 2 & 5 & 7 & 13,7 \\
\hline & Fronliner & 3 & 16 & 19 & 37,3 \\
\hline & Marketing & 10 & 3 & 13 & 25,5 \\
\hline & Back Office & 8 & 4 & 12 & 23,5 \\
\hline
\end{tabular}

Tabel 2. Uji reliabilitas laki-laki dan perempuan Bank BNI Syariah Bogor

\begin{tabular}{clcclc}
\hline \multicolumn{1}{c}{ Laki-laki } & \multicolumn{3}{c}{ Perempuan } \\
\hline Kode & \multicolumn{1}{c}{ Keterangan } & Cronbach Alpha & Kode & \multicolumn{1}{c}{ Keterangan } & Cronbach Alpha \\
\hline X1 & Pengetahuan & 0,930 & X1 & Pengetahuan & 0,959 \\
X2 & Keterampilan kerja & 0,782 & X2 & Keterampilan kerja & 0,942 \\
X3 & Perilaku & 0,889 & X3 & Perilaku & 0,941 \\
X4 & Pengalaman kerja & 0,873 & X4 & Pengalaman kerja & 0,923 \\
\hline
\end{tabular}

Jika koefisien Alpha Cronbach untuk masing-masing variabel lebih besar dari 0,60 sehingga data dinyatakan reliabel. 
Tabel 3. Hasil uji validitas karyawan laki-laki dan perempuan Bank BNI Syariah Bogor

\begin{tabular}{cccccccccc}
\hline & \multicolumn{1}{c}{ Laki-laki } & \multicolumn{7}{c}{ Perempuan } \\
\hline & $\mathrm{X} 1$ & $\mathrm{X} 2$ & $\mathrm{X} 3$ & $\mathrm{X} 4$ & & $\mathrm{X} 1$ & $\mathrm{X} 2$ & $\mathrm{X} 3$ & $\mathrm{X} 4$ \\
\hline X1 (P-Val) & 0 & 0 & 0 & 0 & $\mathrm{X} 1$ (P-Val) & 0 & 0 & 0 & 0 \\
X2 (P-Val) & 0 & 0 & 0 & 0 & X2 (P-Val) & 0 & 0 & 0 & 0 \\
X3 (P-Val) & 0 & 0 & 0 & 0 & X3 (P-Val) & 0 & 0 & 0 & 0 \\
X4 (P-Val) & 0 & 0 & 0 & 0 & X4 (P-Val) & 0 & 0 & 0 & 0 \\
\hline Total & 0 & 0 & 0 & 0 & Total & 0 & 0 & 0 & 0 \\
\hline
\end{tabular}

Keterangan:

$\mathrm{X} 1$ : Pengetahuan

$\mathrm{X} 2$ : Keterampilan kerja

$\mathrm{X} 3$ : Perilaku

Hipotesis untuk masing-masing butir pertanyaan (X1,X2,X3, dan X4)

$\mathrm{X} 4$ : Pengalaman kerja

H0: Tidak ada korelasi antara butir pertanyaan dengan variabel

H1: Ada korelasi antara butir pertanyaan dengan variabel

Jika P-val < alpha (5\%) maka tolak H0

Dari Gambar 2 dan Gambar 3 terlihat pada uji asumsi klasik secara eksploratif pada uji normal terpenuhi baik laki-laki dan perempuan karena titik-titik berada di sekitar garis linear pada grafik normal probability plot. Uji kehomogenan ragam juga terpenuhi karena titiktitik merah di versus fits tidak membentuk pola tertentu. Uji kebebasan sisaan (auto-korelasi) juga terepenuhi jika dilihat karena sisaan data tidak membentuk pola konvergen atau divergen pada plot versus order. Secara keseluruhan untuk uji asumsi klasik eksploratif dapat terpenuhi.

Uji formal yang dilakukan pada penelitian ini yang pertama yaitu uji kehomogenan ragam dengan menggunakan uji gletsjer. Uji gletser dilakukan dengan cara meregresikan absolute sisaan kinerja karyawan dengan seluruh peubah bebas, berikut tabel hasil kehomogenan ragam karyawan laki-laki dan perempuan.

Tabel 4 merupakan hasil uji kehomogenan ragam yang menggunakan uji gletser memiliki hasil nilai P-val untuk laki-laki sebesar 0,268 dan perempuan diperoleh hasil nilai P-val sebesar 0,612, semua hasil P-val yang diperoleh tersebut memilki nilai lebih besar dari $\alpha(0,05)$ maka terima H0. Artinya, kesimpulannya ragam sisaan bersifat homogen baik karyawan laki-laki maupun karyawan perempuan. Dengan kata lain baik laki-laki dan perempuan seluruh pengukuran variabelvariabel yang diukur memiliki informasi yang sama pentingnya, atau setiap pengamatan yang dilakukan peneliti mengandung informasi yang sama pentingnya.

Uji normal yang kedua dilakukan dengan uji normalitas menggunakan uji kolmogorov smirnov. Uji normalitas dengan melihat sebaran titik yang berada pada garis linear.
Uji kolmogorov smirnov ini selain dilihat penyebaran titik-titik yang disekitar garis linear pada Gambar 2 dan Gambar 3 untuk grafik normal probability plot, dapat dilihat juga hasil P-val jika lebih besar dari 5\% maka residual menyebar normal. Tabel 5 hasil P-val yang diperoleh 0,15 dan 0,077 , dengan hasil tersebut lebih besar dari $\alpha(0,05)$ sehingga diperoleh hasil sisaan (residual) menyebar normal baik karyawan laki-laki dan perempuan. Artinya, pada uji ini, hasil yang diperoleh pada masing-masing variabel yang ditentukan bersifat normal.

Uji formal yang ketiga yaitu dilakukan uji kebebasan sisaan dengan menggunakan uji durbin watson atau disebut juga uji autokorelasi yang dapat didefinisikan sebagai hubungan (korelasi) antara anggota observasi yang diurutkan menurut waktu (time series) atau ruang (cross section) menurut Gujarati (2003). Berdasarkan tabel durbin watson (DW) diperoleh batas-batas antara laki-laki dan perempuan selengkapnya pada Tabel 6 .

Hasil DW yang diperoleh untuk karyawan laki-laki diperoleh nilai DW sebesar 1,77506 dan untuk karyawan perempuan menunjukkan nilai DW sebesar 2,02211 (Tabel 7). Hasil estimasi laki-laki dan perempuan didapatkan terletak pada daerah bebas autokorelasi oleh sebab itu dapat disimpulkan bahwa tidak terdapat penyimpangan asumsi klasik autokorelasi baik positif maupun negatif pada model dalam penelitian ini, kasus ini juga menunjukkan bahwa kesimpulannya berada pada zone of indecision. Dimana nilai DW masih diatas 1,5 masih dapat diterima. Artinya, proses pengisian kuesioner memenuhi cara pengisian yang tidak menyebabkan autokorelasi. 

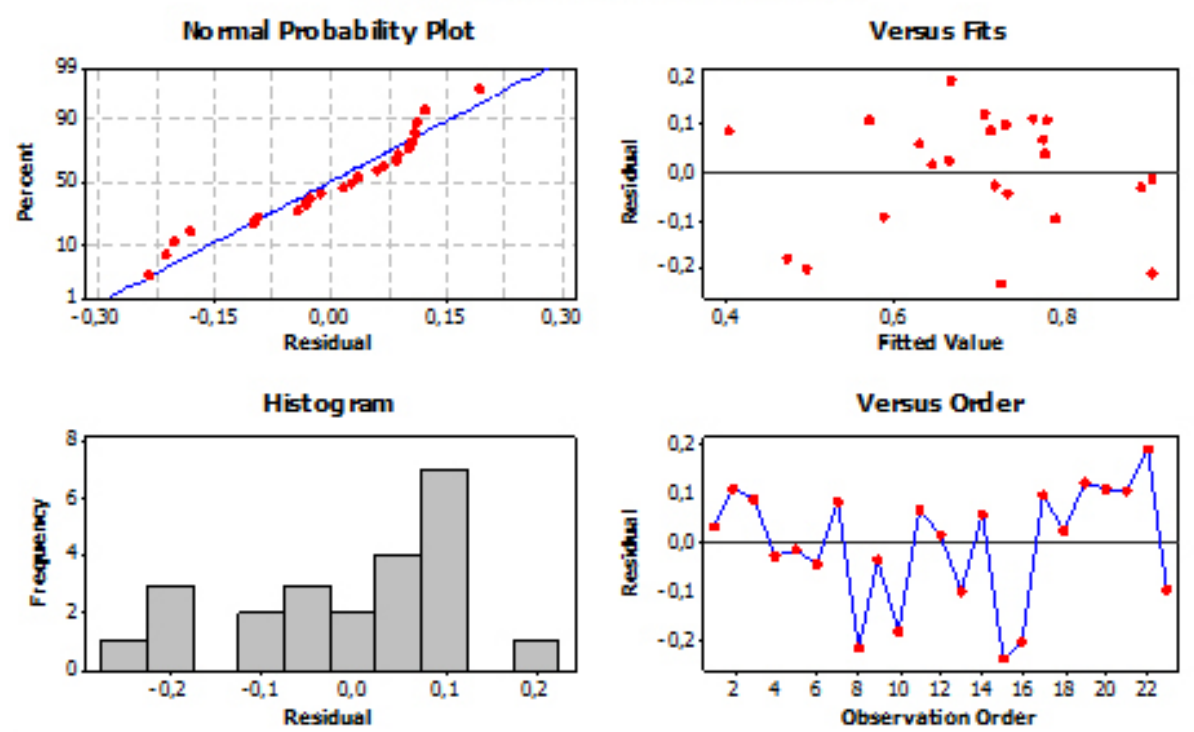

Gambar 2. Grafik uji asumsi klasik secara eksploratif kinerja karyawan laki-laki
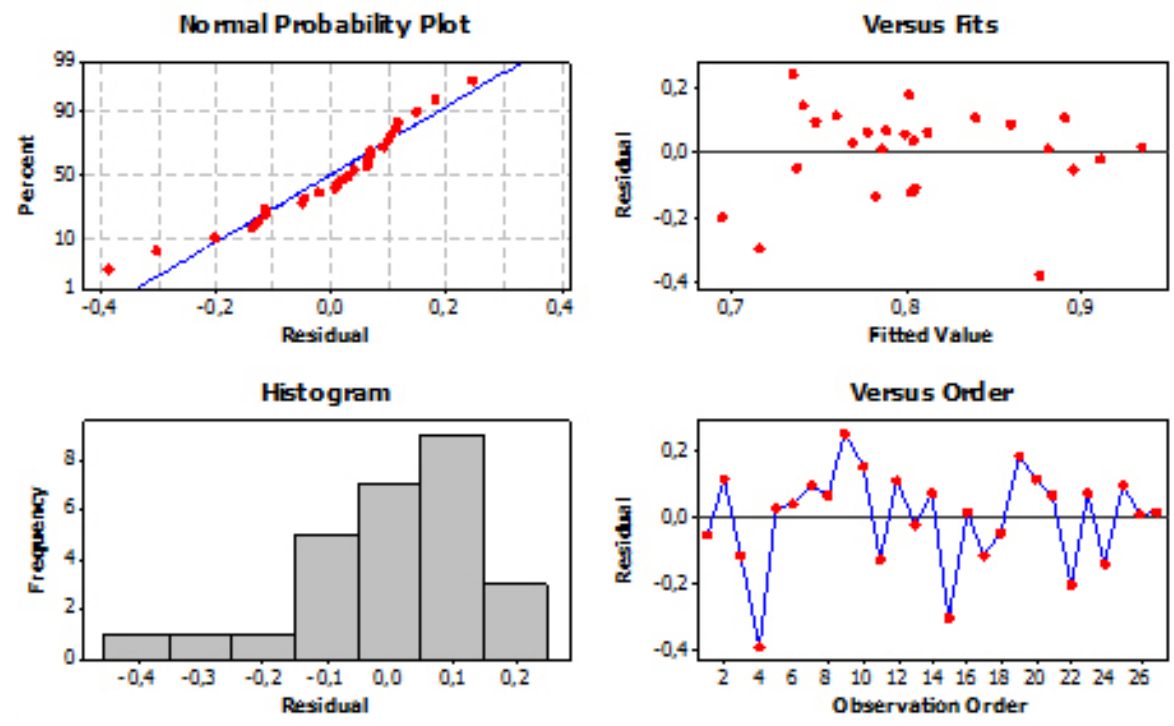

Gambar 3. Grafik uji asumsi klasik secara eksploratif kinerja karyawan perempuan

Tabel 4. Hasil uji kehomogenan ragam menggunakan uji gletser

\begin{tabular}{lc}
\hline \multicolumn{1}{c}{ Jenis Kelamin } & Nilai P-Val \\
\hline Laki-laki & 0,268 \\
Perempuan & 0,612 \\
\hline
\end{tabular}

Hipotesis-hipotesis yang diperoleh:

H0 : Ragam Sisaan bersifat Homogen

H1 : Ragam Sisaan bersifat Heterogen

Jika P-Val $<\alpha(0,05)$ maka tolak H0

Jika P-Val $>\alpha(0,05)$ maka terima $\mathrm{H} 0$
Tabel 5. Hasil uji normalitas menggunakan uji kolmogorov smirnov

\begin{tabular}{lc}
\hline \multicolumn{1}{c}{ Jenis Kelamin } & Nilai P-Val \\
\hline Laki-laki & 0,150 \\
Perempuan & 0,077 \\
\hline
\end{tabular}

Hipotesis-hipotesis yang diperoleh:

$\mathrm{H} 0$ : Residual menyebar normal

H1 : Residual tidak menyebar normal

Jika P-Val $<\alpha(0,05)$ maka tolak H0 
Tabel 6. Batas-batas yang diperoleh berdasarkan durbin watson laki-laki dan perempuan

\begin{tabular}{cccccc}
\hline \multicolumn{7}{c}{ Laki-laki } \\
\hline 0 & $\mathrm{dl}$ & $\mathrm{du}$ & $4-\mathrm{du}$ & $4-\mathrm{dl}$ & 4 \\
0 & 0,9864 & 1,7855 & 2,2145 & 3,0136 & 4 \\
\hline \multicolumn{7}{c}{ Perempuan } \\
\hline 0 & $\mathrm{dl}$ & $\mathrm{du}$ & $4-\mathrm{du}$ & $4-\mathrm{dl}$ & 4 \\
0 & 1,0836 & 1,7527 & 2,2473 & 2,9164 & 4 \\
\hline
\end{tabular}

Tabel 7. Hasil durbin watson karyawan Bank BNI Syariah Bogor

\begin{tabular}{lc}
\hline \multicolumn{1}{c}{ Jenis Kelamin } & Nilai DW \\
\hline Laki-laki & 1,77506 \\
Perempuan & 2,02211 \\
\hline
\end{tabular}

Uji Formal terakhir yang dilakukan, yaitu Uji Multikolinieritas bertujuan menguji apakah model regresi ditemukan adanya hubungan yang kuat diantara variabel independen. Rolph et al. (1998) mengemukakan cara untuk mengetahui ada tidaknya multikolinearitas, yaitu dengan melihat besarnya nilai toleransi value atau Variance Inflation Factor (VIF). Apabila nilai VIF lebih kecil dari 0,10 atau lebih besar dari 10 maka terjadi multikolinearitas dan juga sebaliknya.

Nilai VIF dalam penelitian ini dapat dilihat pada Tabel 8 yang diperoleh hasil untuk laki-laki dan perempuan lebih besar 0,1 dan dibawah 10 sehingga dapat disimpulkan tidak ada multikolinearitas antar peubah bebas. Artinya, untuk uji mutikolinearitas masingmasing variabel tidak ada hubungan yang kuat terhadap variabel lain, dengan kata lain hasil yang diukur pada masing-masing variabel berpengaruh terhadap variabel dependen atau kinerja karyawan Bank BNI Syariah Bogor.

Dari pengujian asumsi klasik yang dilakukan terhadap persamaan regresi menyimpulkan bahwa persamaan tersebut layak digunakan sebagai model persamaan matematis. Selanjutnya, pengujian yang dilakukan adalah pengujian hipotesis penelitian yang meliputi Uji F dan Uji t. Hasil dari pengujian tersebut dilakukan untuk mengetahui ada tidaknya pengaruh variabel independen dengan variabel dependen. Uji $F$ dapat dilakukan secara keseluruhan (bersama-sama) terhadap kinerja karyawan, yaitu dengan membandingkan nilai F-hitung dengan F-tabel, bila F-hitung $>$ F-tabel atau nilai probabilitas signifikansi lebih kecil dari tingkat alfa yang dipilih maka variabel independent secara bersama-sama berpengaruh terhadap variabel dependen. Hasil Uji F untuk karyawan laki-laki dan perempuan.

Hasil Uji F pada Tabel 9 untuk karyawan laki-laki menunjukkan nilai P-Val $(0,005)<\alpha(0,05)$ maka Tolak H0, sehingga dapat ditarik kesimpulan pada Uji F ini model yang digunakan signifikan artinya semua peubah yang digunakan dapat memengaruhi kinerja karyawan. Akan tetapi berbeda dengan hasil Uji F pada karyawan perempuan menunjukkan P-Val $(0,412)>\alpha$ $(0,05)$ maka tidak tolak H0. Artinya, secara keseluruhan variabel pengetahuan, keterampilan kerja, perilaku, dan pengalaman kerja pada karyawan perempuan tidak memengaruhi kinerja karyawan.

\section{Perbedaan Kualitas Kinerja Karyawan BNI Syariah Berdasarkan Jenis Kelamin}

Selain dilakukan Uji F, untuk menguji pengaruh antara variabel independen terhadap variabel dependen sendiri sendiri (parsial) menggunakan Uji t dengan mengasumsi bahwa variabel yang lain dianggap konstan. Berikut hasil Uji t yang didapat untuk karyawan laki-laki dan perempuan.

Hasil Uji t pada Tabel 10 untuk karyawan laki-laki menunjukkan variabel yang berpengaruh nyata hanya perilaku (X3) dan pengalaman kerja (X4), karena hasil P-Val $(X 3=0,072$ dan X4 =0,065) dari kedua variabel ini $<10 \%$. Dapat diperoleh kesimpulan bahwa perilaku dan pengalaman kerja memiliki hubungan linear atau berpengaruh positif terhadap kinerja karyawan Bank BNI Syariah Cabang Bogor. Pada karyawan perempuan hasil P-Val $>10 \%$. Artinya, dari masingmasing variabel yang diukur tidak ada satupun yang menunjukkan pengaruh yang nyata terhadap variabel independen. 
Tabel 8. Hasil nilai VIF pada karyawan laki-laki dan perempuan

\begin{tabular}{clc}
\hline \multicolumn{1}{c}{ Laki-laki } \\
\hline Kode & \multicolumn{1}{c}{ Keterangan } & Nilai VIF \\
\hline X1 & Pengetahuan & 1,574 \\
X2 & Keterampilan Kerja & 1,309 \\
X3 & Perilaku & 1,554 \\
X4 & Pengalaman Kerja & 1,376 \\
\hline \multicolumn{2}{c}{ Perempuan } \\
\hline Kode & \multicolumn{1}{c}{ Keterangan } \\
\hline X1 & Pengetahuan & Nilai VIF \\
X2 & Keterampilan Kerja & 2,041 \\
X3 & Perilaku & 2,032 \\
X4 & Pengalaman Kerja & 1,520 \\
\hline
\end{tabular}

Tabel 9. Hasil Uji F

\begin{tabular}{lc}
\hline \multicolumn{1}{c}{ Jenis Kelamin } & Nilai P-val Uji F \\
\hline Laki-Laki & 0,005 \\
Perempuan & 0,412 \\
\hline
\end{tabular}

Tabel 10. Hasil Uji t karyawan laki-laki

\begin{tabular}{clc}
\hline \multicolumn{1}{c}{ Laki-laki } \\
\hline Kode & \multicolumn{1}{c}{ Keterangan } & Nilai P-val Uji t \\
\hline X1 & Pengetahuan & 0,618 \\
X2 & Keterampilan Kerja & 0,385 \\
X3 & Perilaku & 0,072 \\
X4 & Pengalaman Kerja & 0,065 \\
\hline \multicolumn{2}{c}{ Perempuan } \\
\hline Kode & \multicolumn{1}{c}{ Keterangan } \\
\hline X1 & Pengetahuan & Nilai P-val Uji t \\
X2 & Keterampilan Kerja & 0,112 \\
X3 & Perilaku & 0,659 \\
X4 & Pengalaman Kerja & 0,878 \\
\hline
\end{tabular}

Keterangan:

Tingkat taraf nyata yang digunakan yaitu $10 \%$ dikarenakan asumsi yang berlaku yaitu kasus sosial, untuk kasus sosial dapat menggunakan tingkat taraf nyata $10 \%$. Jika P-Val $<10 \%$ maka variabel dependen berpengaruh terhadap independen.

\section{Perumusan Variabel-Variabel yang Meningkatkan Kualitas Kinerja BNI Syariah Bogor}

Persamaan regresi yang diperoleh untuk karyawan laki-laki, yaitu $\mathrm{Y} 1=0,074+0,082 \mathrm{X} 1+0,167 \mathrm{X} 2$ $+0,399 \mathrm{X} 3+0,392 \mathrm{X} 4$. Berdasarkan Uji t yang diperoleh, bahwa kinerja karyawan laki-laki pada Bank BNI Syariah Cabang Bogor hanya dipengaruhi oleh variabel perilaku dan pengalaman kerja maka interpretasi dari persamaan regresi hanya diberikan kepada kedua variabel ini. Artinya, apabila perilaku meningkat sebesar $1 \%$ (dengan asumsi peubah lain tetap) maka rata-rata dari poin kinerja karyawan akan meningkat atau berhubungan positif sebesar 39,9\%, apabila variabel pengalaman kerja meningkat sebesar $1 \%$ (dengan asumsi peubah lain tetap) maka rata-rata dari point Kinerja Karyawan akan meningkat atau berhubungan positif sebesar 39,2\%. Untuk mengetahui sampai seberapa besar presentase variasi variabel bebas pada model dapat diterangkan oleh variabel terikat, maka digunakan koefisien determinasi atau R-squared (Gujarati, 2003). Hasil tabel R-squared kinerja karyawan Bank BNI Syariah Cabang Bogor dijelaskan pada Tabel 11.

Tabel 11. Hasil persentase R-squaredkinerja karyawan

\begin{tabular}{lc}
\hline \multicolumn{1}{c}{ Jenis Kelamin } & Nilai R-sq \\
\hline Laki-Laki & $54 \%$ \\
Perempuan & $15,8 \%$ \\
\hline
\end{tabular}

Nilai R-squared pada Tabel 11 untuk karyawan lakilaki sebesar 54\%, artinya keragaman yang yang dapat dijelaskan oleh model adalah sebesar 54\% sedangkan sisanya sebesar $46 \%$ dijelaskan oleh faktor lainnya yang berada di luar model. Persamaan regresi yang diperoleh untuk karyawan perempuan pada Bank BNI Syariah Cabang Bogor, yaitu Y2 = 0,676 + 0,333X10,088X2 - 0,033X3 + 0,055X4. Berdasarkan Uji t yang diperoleh untuk karyawan perempuan Bank BNI Syariah Cabang Bogor bahwa tidak ada satupun variabel yang memengaruhi kinerja karyawan. Nilai R-squared karyawan perempuan sebesar 15,8\%. Artinya, keragaman yang yang dapat dijelaskan oleh model adalah sebesar $15,8 \%$, sedangkan sisanya sebesar $84,2 \%$ dijelaskan oleh faktor lainnya yang berada di luar model.

\section{Implikasi Manajerial}

Hasil penelitian menunjukkan bahwa karyawan laki-laki pada Bank BNI Syariah cabang Bogor untuk variabel perilaku dan pengalaman kerja terdapat pengaruh yang positif dan signifikan terhadap kenerja karyawan. Oleh karena itu, berikut akan diurai implikasi manajerial berdasarkan hasil penelitian ini. Beberapa tahun belakangan ini Bank Syariah lebih diminati oleh nasabah dalam peningkatan perekonomian, karena sesuai dengan aturan syariah secara islam. Bank BNI Syariah menjadi salah satu bank syariah yang cepat perkembangannya di Indonesia. Oleh karena itu, karyawan Bank BNI Syariah dituntut untuk bekerja lebih berkualitas. Salah satu faktor yang mendukung dalam kinerja karyawan 
yaitu jenis kelamin atau gender, pada faktor gender variabel-variabel yang diambil dalam penelitian ini, yaitu pengetahuan, keterampilan kerja, perilaku, dan pengalaman kerja. Variabel-variabel tersebut diambil yang sependapat dengan Gibson (1996) secara teroritis variabel-variabel yang memengaruhi kinerja yaitu variabel pengetahuan, keterampilan kerja, perilaku dan pengalaman kerja.

Menurut Mangkunegara (2000) faktor-faktor yang memengaruhi pencapaian kinerja adalah pengetahuan (knowledge), keterampilan (skill), dan faktor motivasi (motivation). Variabel-variabel tersebut hanya beberapa variabel yang diukur untuk meningkatkan kualitas kinerja karyawan. Melalui penelitian ini diharapkan bisa dijadikan referensi untuk manajemen Bank BNI Syariah Bogor dalam proses dan penerimaan karyawan baru. Jika kedepannya Bank BNI Syariah Bogor dalam melakukan penerimaan pegawai baru, mungkin lebih dikaitkan dalam unsur (variabel) perilaku dan pengalaman kerja untuk calon karyawan laki-laki. Untuk proses perekrutan dan penerimaan calon karyawan perempuan, pada penelitian ini unsur-unsur yang digunakan tidak berhubungan dengan peningkatan kinerja karyawan. Penelitian ini hanya sebatas analisis yang dilakukan peneliti saja dan hanya mencakup penilaian kinerja karyawan Bank BNI Syariah yang bekerja di wilayah Bogor.

\section{KESIMPULAN DAN SARAN}

\section{Kesimpulan}

Sesuai analisis regresi berganda dengan variabelvariabel yang dilakukan dapat disimpulkan yaitu untuk menganalisis hubungan karakteristik karyawan Bank BNI Syariah Cabang Bogor dengan kinerja karyawan, karyawan yang berdominasi memengaruhi kinerja di Bank BNI Syariah Bogor yaitu karyawan yang rata-rata usianya antara 26-30 tahun, tingkat pendidikan terakhir yaitu sarjana (S1), memiliki lama bekerja 2-5 tahun, kebanyakan responden yang diuji pada penelitian ini memiliki posisi atau jabatan sebagai frontliner.

Secara keseluruhan variabel-variabel yang digunakan untuk meningkatkan kualitas kinerja karyawan lakilaki dan perempuan di Bank BNI Syariah Cabang Bogor dalam penelitian ini, yaitu pengetahuan, keterampilan kerja, perilaku, dan pengalaman kerja. Setelah dianalisa dan diperoleh hasil pada Uji Validitas seluruh variabel memiliki nilai $\mathrm{P}-\mathrm{Val}<5 \%$ sehingga dapat ditarik kesimpulan variabel-variabel yang diukur pada penelitian ini dapat diterima dan dapat dilakukan pengujiannya.

Hasil analisis secara kualitas untuk karyawan laki-laki yang berjumlah 23 orang, sesuai Uji t yang dilakukan hanya pada variabel perilaku dan pengalaman kerja saja yang memiliki nilai $\mathrm{P}$-Val $<\alpha(0,1)$ dengan masing-masing nilai sebesar 0,072 dan 0,065. Artinya, karyawan laki-laki di Bank BNI Syariah Cabang Bogor yang berjumlah 23 orang untuk kualitas kinerja karyawan hanya dipengaruhi oleh variabel perilaku dan pengalaman kerja saja. Hasil Uji t yang dilakukan untuk karyawan perempuan yang berjumlah 28 orang, semua variabel yang diperoleh memiliki nilai P-Val $>\alpha(0,1)$. Artinya, dari semua variabel yang diukur pada penelitian ini tidak ada satupun variabel yang memengaruhi kinerja karyawan perempuan di Bank BNI Syariah Cabang Bogor.

Setelah dilakukan pengujian pada karyawan Bank BNI Syariah Cabang Bogor, dapat ditarik kesimpulan hanya karyawan laki-laki yang dapat meningkatkan kualitas kinerja, tetapi dengan catatan pada penelitian ini untuk karyawan laki-laki variabel yang dapat memengaruhi dan meningkatkan kinerja karyawan hanya variabel perilaku dan pengalaman kerja saja.

\section{Saran}

Penelitian ini hanya dilakukan sebatas ruang lingkup yang kecil. Oleh karena itu, saran peneliti untuk penelitian kedepannya agar menggunakan ruang lingkup yang lebih luas lagi seperti wilayah kerja provinsi atau secara nasional. Analisis yang dilakukan pada penelitian ini hanya beberapa variabel sosial yang diukur sehingga penelitian kedepannya bisa ditambahkan variabel-variabel yang diukur

\section{DAFTAR PUSTAKA}

Channar ZA, Abbassi Z, Ujan IA. 2011. Gender discrimination in workforce and its impact on the employees. Pakistan Journal of Commerce and Social Sciences 5(1): 177-191.

Cornell DG, Peterson CS, and Richards H. 1999. Anger as a predictor of aggression among incarcerated adolescent. Journal of Consulting and Clinical Psychology 62(1): 108-115. 
Dimovski V, Skerlavaj M, Man MMM. 2010. Is there a 'glass ceiling' for female managers in singapore organizations?. Management 5 (4): 307-329.

Edrak BB, Yin Fah BC, Gharleghi B, Seng TK. 2013. The effectiveness of intrinsic and extrinsic motivations: a study of malaysian amway company's direct sales forces. International Journal of Business and Social Science 4(9): 96-103.

Eisner SP, Harvey MEO. 2009. C Change? generation $\mathrm{y}$ and the glass ceiling? SAM Advanced Management Journal 74(1): 13-28.

Ekowarni E. 2001. Pola perilaku sehat dan model pelayanan kesehatan remaja. Jurnal Psikologi 2:97-104.

Gibson, James L. Rt al, 1996. Orgainasasi: perilaku, struktur, proses, Jilid 1, terjemahan Djarkosih. Jakarta: Penerbit Erlangga.

Gujarati D. 2003. Basics Econometrics. Edition 4th. Singapore: McGraw-Hill

Rolph EA, William B, Joseph FH, Ronald LT. 1998. Multivariate Data Analysis, 5th Edition, Upper Sadle River. New Jersey: Prentice Hall International Inc.

Hersey P, blanchard KH. 1992. Manajemen Perilaku Organisasi: Pemberdayaan Sumber Daya Manusia. Dharma A, penerjemah. Jakarta: Erlangga.

Herzberg F. 1974. Motivation-higienes profiles. Organization Dynamic 3(2):18-29.

Jamal M. 1984. Job stress and job performance controversy: An empirical assessment. Organisation Behaviour and Human Performance 32:1-21.

John L, Stephen W, Karen AF. 2008. Theories of Human Communication, ninth edition. Belmont: Thomson Wadsworth.

Lips HM. 1993. Sex and Gender: An Introduction. London: Myfield Publishing Company.

Mangkunegara AP. 2000. Manajemen Sumber Daya Manusia Perusahaan. Cetakan Pertama. Bandung: Remaja Rosda Karya.

Mathie RL, Jackson JH. 2006. Manajemen Sumber Daya Manusia. Ed Ke-5. Sadeli J, Hie BP, penerjemah. Jakarta: Salemba Empat.

Prawirosentono. 1999. Manajemen Sumber Daya Manusia Kebijakan Kinerja Karyawan. Yogyakarta: BPFE.

Putri PKD. 2015. Pengaruh tingkat pendidikan, pengetahuan, sikap dan terpaan iklan layanan masyarakat KB versi Shireen Sungkar dan Teuku Wisnu di TV terhadap perilaku KB pada wanita atau pria dalam usia subur. Jurnal Interaksi 63:1-5.

Riorini SV. 2004. Quality performance dan komitmen organisasi. Jurnal Media Riset Bisnis dan Manajemen 4 (3): 253-274.

Rivai HA, Lukviarman N, Syafrizal, Lukman S, Andrianus F, Masrizal. 2006. Identifikasi faktor penentu keputusan konsumen dalam memilih jasa perbankan: bank syariah vs bank konvensional. Jurnal Bank Indonesia 5(2): 3-5.

Rivai V, Ahmad FM, Basri Ella JS, Silviana M. 2011. Performance Appraisal (Sistem yang Tepat untuk Menilai Kinerja Karyawan dan Meningkatkan Daya Saing Perusahaan) Edisi Kedua, Cetakan 4. Jakarta: PT Raja Grafindo Persada.

Robbins SP. 2002. Perilaku Organisasi: Konsep, Kontroversi dan Aplikasi. jilid Ke-1 dan Ke-2, Ed Bahasa Indonesia. Pujaatmaka, penerjemah. Jakarta (ID): Prehallindo.

Setiawan J. 2015. Pengaruh perbedaan gender dan keterampilan kerja terhadap produktivitas pada PT Pilbara Insulation Southeast Asia. Jurnal AKMENDIS. Akademi Akuntansi Permata Harapan 4(1): 64-79.

Siddiqah L. 2010. Pencegahan dan penanganan perilaku agresif remaja melalui pengelolaan amarah (anger management). Jurnal Psikologi 37(1): 50-64.

Sulaeman A. 2014. Pengaruh upah dan pengalaman kerja terhadap produktivitas karyawan kerajinan ukiran Kabupaten Subang. Jurnal Trikonomika. 13(1): 91-100.

Showalter E. 1989. Speaking of Gender. New York \& London: Routledge.

Syafi'i. 2015. Implementasi produk tabungan umum syariah di KJKS BMT UGT Cabang Sidogiri Cabang Pembantu Tlanakan Pamekasan. Jurnal Ekonomi dan Bisnis STAIN Pamekasan 4:1248.

Waterhouse J, Svendsen A. 1998. Strategic Performance Monitoring and Management: Using Non Financial Measures to Improve Cor porate Governence. Quebec: The Canadian Institute of Chartered Accountant 18: 69-82.

Wijayanti. 2009. Glass ceiling dalam karir wanita mampukah wanita mengatasi glass ceiling? Jurnal Manajemen dan Bisnis 2: 29-42. 
Zainullah A. 2012. Pengaruh upah, kemampuan dan pengalaman kerja terhadap kinerja pekerja pelaksanaan bekisting pada pekerjaan beton. Jurnal Rekayasa Sipil 6: 1-5.
Zameer H, Ali S, Nisar W, Amir M. 2014. The impact of the motivation on the employee's performance in beverage industry of Pakistan. International Journal of Academic Research in Accounting, Finance and Management Sciences 4(1): 293298. 